\title{
SISTEMAS AGROFLORESTAIS PECUÁRIOS COM ÊNFASE NAS ESPÉCIES ARBÓREAS E/OU ARBUSTIVAS FORRAGEIRAS
}

\author{
Pâmela Dias de Oliveira' ${ }^{1}$; Rosana Quaresma Maneschy² \\ ${ }^{1}$ Discente de Agronomia, Faculdade de Ciências Agrárias de Marabá (FCAM), Universidade Federal do Pará (UFPA), \\ Marabá, Pará, Bolsista FAPESPA. E-mail: pamelannine@gmail.com. \\ ${ }^{2}$ Engenheira Agrônoma, Prof. ${ }^{\text {, }, ~ D . S c ., ~ F C A M, ~ U F P A . ~ E-m a i l: ~ r o m a n e s c h y @ u f p a . b r . ~}$
}

RESUMO: A pecuária é considerada uma atividade impactante na Amazônia e relacionada aos desmatamentos. A comunidade científica juntamente com os produtores têm buscado alternativas para minimizar os impactos ambientais, aumentando a sustentabilidade desses sistemas de produção. Os Sistemas Silvipastoris e Agrosilvipastoris associam componentes arbóreos e pastos aos cultivos anuais. Esses sistemas permitem, dentro de uma perspectiva de desenvolvimento sustentável, a mitigação de seus impactos ambientais tradicionais da atividade pecuária, permitindo aumento da biodiversidade, uso conservacionista do solo, e a conservação da água. A utilização de leguminosas arbóreo-arbustivas permite a arborização dos pastos fornecendo sombra para o gado, favorece a ciclagem de nutrientes e podem produzir produtos adicionais tais como: madeira, estacas, postes, mourões, lenha e outros. Como exemplo dessas leguminosas forrageiras pode-se citar a leucena (Leucaena leucocephala (Lam.) de Wit.) e a cratylia (Cratylia argentea (Desv.) O. Kuntze). Este trabalho tem como objetivo difundir os sistemas agroflorestais pecuários (SAFP) com lenhosas forrageiras de alta qualidade nutricional para suplementar a alimentação animal, no contexto da agricultura familiar. O trabalho será desenvolvido no Projeto de Assentamento Belo Horizonte I, situado à altura do km 30 da BR-153, no município de São Domingos do Araguaia, na microrregião de Marabá. O clima no local é Am no limite de transição para Aw com temperatura média anual de $26,3^{\circ} \mathrm{C}$. O solo é o podzólico vermelho amarelo com textura argilo-arenosa. A metodologia utilizada é da pesquisa-ação e participativa que visa à construção de inovações em parcerias com agricultores. A construção da parceria e tomada de decisão das ações prioritárias será em três fases. A primeira fase será a realização de um diagnóstico; A segunda será de sensibilização dos agricultores da importância do componente arbóreo na pastagem; e a terceira será de intervenção, com a realização de cursos, elaboração dos planos de implementação de cada açãoteste, implantação e acompanhamento dessas ações, de forma conjunta. Será feito reunião com os agricultores interessados em desenvolver ações-testes e levantamento sobre o conhecimento local a respeito do SAFP. As atividades desenvolvidas serão de testes em meio real e visam à construção de inovações em parcerias com agricultores. Será escolhida pelos agricultores qual (ais) lenhosa (as) forrageira (s) apresentada (s) pelo projeto irão ser testadas. As mudas serão produzidas na casa de vegetação, Viveiro Nascimento, da Faculdade de Ciências Agrárias de Marabá - UFPA, e serão transportadas até o P. A. para as ações. Serão realizadas reuniões de avaliações das atividades onde será aplicada a técnica de Diagnóstico Rápido Participativo para analisar o conhecimento adquirido da comunidade a partir das atividades desenvolvidas nessa ação. As plantas serão avaliadas quanto a: sobrevivência, altura total $(\mathrm{m})$ e diâmetro do coleto $(\mathrm{cm})$ mensalmente durante um ano. A partir de 1,50 m de altura serão avaliadas diâmetro a altura do peito - DAP $(\mathrm{cm})$ e diâmetro de copa - DC (m). Espera-se difundir os SAFP com lenhosas forrageiras de alta qualidade nutricional para suplementar a alimentação animal, através da troca de conhecimentos e experiências entre agricultores, técnicos, pesquisadores e estudantes em busca de melhorias nos sistemas de criação de bovinos.

PALAVRAS-CHAVE: Leucena, cratylia, pesquisa participativa. 